\title{
Ethnological Analysis of the Process of the Post-War Migration of Slovaks from Hungary to Czechoslovakia in the Years 1946-1948
}

\author{
MAGDALÉNA PARÍKOVÁ
}

Department of Ethnology and Ethnomusicology, Constantine the Philosopher University in Nitra

mparikova@ukf.sk

\begin{abstract}
The article focuses on the application of the possibilities of collecting narratives and their analysis in the reconstruction process of migration of people to the new country in Slovakia. The analysis of the particular data gained by fieldwork research using the oral history method comparative with the historical and statistic dates. These facts offer not only relevant information documenting the real process of the migration, but also create the network of microprobes (case study) on the basis of specific experienced events of the direct participants of migration, as well as the reflection in memory of the resettled. Fieldwork research was in the region of South Slovakia - around Nové Zámky and Komárno cities. The aim of this approach is to interpret individually experience "small history" of the context of "big history", specifically, one post-war phase of migration, which occurred in this area of Central Europe in the period from 1946 to 1948.
\end{abstract}

KEY WORDS: postwar migrations in Europe, resettlement adaptation, integration, ethnocultural and social processes

The period of World War II witnessed mass transfers of people. The war resulted in and predetermined the new geopolitical situation in Europe. The migratory movements of millions of people (mostly non-voluntary) that had taken place already during the war for one reason or another (chiefly Jewish people) were among to the greatest demographic changes in modern historical development of Central and South-Eastern part of Europe in 
particular. These changes were most markedly reflected in the changes of the ethnic composition of the inhabitants in particular regions. Twenty million Germans, Hungarians, Poles, Czechs, Slovaks, Ukrainians, Belorussians, Lithuanians, Hungarians and other ethnic groups illustrate the extent of the particular waves of migrations, which touched several European countries. They had to abandon their homelands as a result of political decisions taken by the post-war powers (USA, Great Britain, USSR). Only a small number of migrants welcomed the opportunity of voluntary resettlement in another country, including those who were offered the opportunity to live permanently in the country of their mother nation.

The essential tendency to the implementation of migrations, immediately after the war was, to "simplify the nationality structure" (KO ŘALKOVÁ 1986:165), not only in Czechoslovakia but also in other European countries. The vast territory of Europe offers examples of the implementation of this 'scenario' and its impact on the population. The shift of the borders of the former Soviet Union westwards (in the area of the Ukraine, Belorussia, and Lithuania) united nations in the area and contributed to the formation of a united nation-state of Poland with its western frontier shifted to the rivers Oder and Neisse. The 1945 Czechoslovak-Soviet treaty and the annexation of Sub-Carpathian Ukraine to the Ukrainian Soviet Socialist Republic also corresponded to the implementation of the nationality principle. From the historical perspective, the most significant change in the nationality structure of several countries of postwar Central Europe came with the decision taken at the Potsdam Conference of the victorious powers, which resulted in the transfer of the German population from Poland, Czechoslovakia, Hungary, and partly from Romania and Yugoslavia in 1945-47. The deportation of the members of the Magyar ethnic group from the territory of former Czechoslovakia and resettlement of members of the Slovak ethnic group in Czechoslovakia took place almost in parallel in 1946-48. It proceeded on the basis of the intergovernmental bilateral Agreement on the exchange of population between Czechoslovakia and Hungary, ratified after complicated negotiations on February, 27th, 1946 (ČIERNA-LANTAYOVÁ 1992). At that time some other intergovernmental treaties were signed and Czechoslovakia accepted a number of Slovak and Czech compatriots who had lived longer abroad (Hungary, Yugoslavia, Romania, Bulgaria, France, Poland, Germany, Austria but also some other countries overseas (ŠUTAJ 2010:11). Their resettlement was done in terms of the specifically defined conditions, which did not obey the principle of reciprocity. The inhabitants of Slovak origin arrived from the western part of sub-Carpathian Ruthenia which became part of the Ukrainian Soviet Socialist Republic in 1945. Those who declared their nationality to be Slovak and their permanent residence was sub-Carpathian Ruthenia had the right to opt for citizenship 
of the Czechoslovak Republic following from the change of the state territory after World War II. In relation to the compatriots abroad (of Slovak and Czech nationality) who were offered to return to Czechoslovakia after World War II, then legal practice distinguished between the concepts of repatriation and re-emigration. It was based on the continuity of legal norms valid before 1938. The main difference - evident not only in different naming of the process, but also in the different status of immigrants after their resettlement in Czechoslovakia - consisted in the fact whether the people had Czechoslovak citizenship in 1938 - if so, it was repatriation. If the return concerned people of Czech or Slovak nationality who had settled abroad on a more permanent basis before 1938, the process was called re-emigration. ${ }^{1}$

There was a close interdependence between the resettlement of a large number of Czechs and Slovaks in postwar Czechoslovakia and the deportation of ethnic Germans and Magyars from its territory. Their emptied houses in a number of localities and towns throughout Czechoslovakia (in Bohemia it was chiefly the border regions, in Slovakia all areas with a mainly German population as well as the places inhabited by Hungarians) provided a new home for the people coming not only from Hungary but also from other European countries.

The postwar migration of the people of Slovak origin from Hungary, that is the process of re-emigration, involved former emigrants, who had began "writing" the history of the Slovak enclaves and the diaspora created in the depopulated regions of former Hungary that were not utilized economically more than two centuries ago. The formation of

Repatriation - the concept concerned the people who had lived abroad - for any reasons - for a limitid time and their decision was to return to Czechoslovakia on a voluntary basis. (Among them there were persons imprisoned or displaced or mobilized for forced labor in Germany or in any place in the occupied territory, soldiers in Czechoslovak foreign armies, their families, and persons who left Czechoslovakia for political reasons after May 1938, when the republic was in danger and later). The decisive point was that they had been Czechoslovak citizens before 1938. The recognition of Czechoslovak citizenship after 1945 was verified on the basis of any pre-war document and a certificate of national reliability. By settling repatriates, their former residents they had to abandon, was usually respected. Re-emigration - concerned, in contrast to repatriation, compatriots (Czechs and Slovaks) whose stay abroad was permanent (already before 1938) and who preserved their language and national awareness but their status of citizenship was other than Czechoslovak or they were so-called homeless people. Persons, who had emigrated for social reasons long before 1938, or those who were born abroad as children of Czech or Slovak emigrants could apply for re-emigration. The essential criterion for the status of re-emigrant was to belong to the Czech or Slovak nation, felt as a stronger bond than the status of different citizenship. Their settlement was not bound to their original residence (or of their ancestors) and their previous occupation was not binding either (KOŘALKOVÁ 1986:162-166). 
MAGDALÉNA PARÍKOVÁ

Ethnological Analysis of the Process of the Post-War Migration of Slovaks from Hungary to Czechoslovakia in the Years 1946-1948

these "Slovak islands" in the territory of former Hungary was interconnected with the historically oldest mass wave of emigration from the Slovak ethnic territory. The most compact territory populated by emigrants in three stages (from the beginning of the 18th century to the turn of the 19th and 20th centuries) was the region of the Low Lands (spread over the borderlines between modem Hungary, Yugoslavia, and Romania), as well as the region of Transdanubia in the northern part of what is today Hungary (SIRÁCKY 1996). A number of new settlements were formed there in the particular stages of settling the territories not inhabited and economically not used then. ${ }^{2}$

After more than two centuries that elapsed from the settlement of emigrants coming from the northern parts of historic Hungary and living in compact and relatively homogeneous and historically fixed islands in various parts of present-day Hungary, a new reality entered the lives of the generations of their descendants after World War II, offering an option to go to live in the territory of their "mother" nation - Slovakia. The domestic and international contexts as well as the contexts of national policy in postwar Czechoslovakia contributed to it, resulting in the intergovernmental bilateral agreement between Czechoslovakia and Hungary. This meant a bilateral population exchange between the two countries. What should be underlined here is that, in contrast to the Slovaks living in Hungary, who agreed to move spontaneously and voluntarily, the deportation of the members of the Magyar ethnic group living in Czechoslovakia was involuntary.

The interest in the resettlement of the Slovaks in particular Slovak enclaves and the diaspora of Hungary was stimulated by six-months' agitation by the contemporary political, economical, cultural, religious and chiefly nationally oriented and nationally conscious representatives of Slovakia. The slogans of the agitation had emotional flavour: "Your Slovak mother is calling you", "Slovaks, come back", which should have encouraged

The causes of this mass population migration come primarily from northern counties of historic Hungary; they were mainly based on the contemporary economic and social conditions of the starting territory and of the target territory. On the one hand there were no favourable conditions for living in the starting territory, on the other hand there were fertile, but uncultivated areas of agricultural land, which provided the incomers with sufficient sources for living and with good conditions for permanent settlement. After the immigrants had settled, a special type of culture and way of life was built there, also thanks to the tenacious and industrious, mostly agrarian, people, very well labelled as a "peasant world". Agricultural production in this area reached a high European standard (BOTíK 1955:433). In addition to the social motivation in the course of the colonization of this territory, the strengthening Counter-Reformation also played a role. It had primarily addressed the immigrants of the Evangelical Augsburg Confession, who later made up the majority of the Slovak incomers. Of course, people of other religions arrived in the following stages of migration (mainly Roman Catholics and Greek Catholics). 
MAGDALÉNA PARÍKOVÁ

Ethnological Analysis of the Process of the Post-War Migration of Slovaks from Hungary to Czechoslovakia in the Years 1946-1948

particularly the nationally conscious Slovak compatriots to resettle and go to live in Slovakia. Distributing those slogans, the Antifascist Union of the Slovaks in Hungary became a significant information centre, which, at that time, intensified its activities among Slovak compatriots not only in Hungary but also in Yugoslavia and Romania. Information about more favourable economic conditions in Czechoslovakia, state support in the search for work, school education in their mother (Slovak) tongue, were part of campaign for reemigration. The pledge to improve social conditions for re-emigrants coming from Hungary relied on the real economic situation in postwar Czechoslovakia, which was indeed more favourable than that of Hungary. In Hungary, a great part of the population lived on the poverty line in that period, there were severe shortages of food and basic needs, increasing inflation, culminating during the exchange of population. It was therefore not surprising that the agitation for the permanent settlement in Slovakia addressed primarily poorer Slovaks in Hungary. The analyses of the contemporary statistics (based on reemigration questionnaires) show they were that mostly small- and medium-scale farmers, hired hands, landless people, unemployed and non-agrarian strata of inhabitants (small entrepreneurs, state employed administrative workers). The numbers of the original applicants for resettlement within particular social categories of the inhabitants of Slovak origin can serve as example. Of the total of 95,421 people enlisted, 6,506 belonged to the lowest category of agrarian workers (owning 0.5-2.5 hectares of land; 1 hectare is about 2.47 acres), 12,630 persons were seasonal workers, 10,829 were miners, craftsmen, people working in transport, and only 211 people of them belonged to a group of farmers owning 10-50 hectares of land (KUGLER 1992).

Families, whose fathers or other family members were in captivity during the war also tended to re-emigrate since the Czechoslovak resettlement bodies promised to help to liberate them and to arrange their return. It should be emphasized, however, that in addition to the social "attractiveness" of resettlement, the dominant motivation of the great part of re-emigrants followed from their conviction and the deeply-rooted feeling of belongingness to the Slovak nation. It was gained in the family setting, maintaining the awareness of belonging to the Slovak ethnic group and the knowledge of the Slovak language (although chiefly only as a dialect). The Slovak minority in Hungary had its intelligentsia mainly among priests (of Evangelical-Augsburg Confession), teachers, but also numerus farmers; their systematic activities of teaching and education (in addition to the compulsory school attendance) as well as reading the bible (written in Czech of Kralická Biblie) preserved the Slovak ethnic awareness and knowledge of Slovak, since its communication function had been increasing confined to the family setting and religious life. That means that the decision of this part of the compatriots in Hungary, primarily seen in school education, 
religious life. That means that the decision of first part the compatriots in Hungary to the reemigrate followed from their will not to submit to the long-lasting assimilation pressure put on the non-Magyar ethnic groups in Hungary, primarily seen in school education, religious life (among Catholics in particular), but also in everyday life and in social communication with the surroundings, To departure of these families from Hungary drastically decreased the number of members of the Slovak minority in the previously compact Slovak settlements und thus also the number of the people seeking to maintain the weakened Slovak ethnic awareness of the inhabitants living in some regions of Hungary (GYIVICSÁN 1993:183).

The population exchange between 1946 and 1948 took place in terms of the treaty on reciprocity concerning not only the number of inhabitants that participated in the exchange but also property reciprocity, that is the possibility to transfer their in the exchange but also property reciprocity, that is the possibility to transfer their possessions, furniture and home appliances, but also the allotment of housing and farmland in the least such an amount as they had possessed in their homeland. The principle of reciprocity was binding for both sides participating in the exchange of populations. In spite of the interest of the political representation of Czechoslovakia to deport as many Hungarians as possible in accord with the idea of the Košice government program [Košický vládny program] about the creation of the "Slavic character" of Czechoslovakia and "deliverance" of the Slovaks living in southern Slovakia and abroad from assimilation (ŠUTAJ 1993:58-59), the policy of implementing this intent - tending to the originally unilateral deportation of the Hungarians - was modified. The number of the Hungarians displaced from Czechoslovakia depended on and was bound to the number of Slovaks applying for resettlement in Hungary. It should be brought to mind that in the case of the Hungarians living in Czechoslovakia, the number of persons to be deported was 68,407 (in addition to about 20-30 thousand persons who left voluntarily) and more than 70,000 Slovaks moved to Czechoslovakia on a voluntary basis. The deportation of ethnic Hungarians followed the criteria associated with political commitment, particularly during the so-called Horthy regime, which were explicitly expressed in the Košice government program of April 5th, 1945. Its chapter 8 contained the exact specification of the groups of inhabitants whom the deportation concerned: first, they were political representatives and adherents of Horthy's 
MAGDALÉNA PARÍKOVÁ

Ethnological Analysis of the Process of the Post-War Migration of Slovaks from Hungary to Czechoslovakia in the Years 1946-1948

regime. ${ }^{3}$ What happened, however, was, that the involuntary deportation afflicted not only those whose political orientation and commitment could have been proved, but also Hungarian people who had no clear political orientation, or were indifferent to politics. They were not given the opportunity to prove their "innocence" and to avoid deportation. Such a possibility concerned only a small group of "antifascists" and "democrats". Only a small number of the people belonging to the Hungarian ethnic group made use of the chance to move to Hungary or any other country and some of them (Jewish people) opted for emigration to Palestine or to the USA (BOBÁK 1996:94).

The property reciprocity proclaimed by the treaty was implemented through questionnaires containing a list of real and personal estate possessed by the inhabitants taking part in resettlement. The questionnaire's aim was to make a transparent survey of the possessions of persons participating in the population exchange, and, in the case of farmers of the size of their farms included in the population exchange; it also contained the data sheet of the person applying for resettlement and his family members. Persons above 18 had to fill in a separate questionnaire. Resettlement and possessions of non-agrarian people (e.g. businessmen, free-lancers), who decided to re-emigrate to Czechoslovakia were defined in special provisions. If the inhabitants belonging to the Hungarian ethnic group selected for deportation from Czechoslovakia welcomed the lengthy political and intergovernmental negotiation - which meant a longer stay in Czechoslovakia - it was a period of tension for the Slovaks in Hungary waiting for the earliest term of departure possible. It was the agricultural people who were particularly impatient waiting for departure because their existence depended on the land as the source of their living and it required the keeping of the cycle of field works not allowing for any delay. The course and the tempo of the population exchange was, however, held back not only by solving the meritorious political issues but also by disparity in the number of persons taking part in the exchange of population as well as the comparison of the possessions on the side of deported Hungarians and the Slovaks coming from Hungary. ${ }^{4}$

For example: member of Hungarian Arrow Cross Party- "Nyilas", who been active in the 1938 occupation of southern Slovakia, member and representatives of the union of Hungarians professors and teachers member of "Procházka kor".

4 Pursuant to the treaty, the inhabitants of Hungarian nationality left in Slovakia 54,647 hectares of land; 1 hectare is about 2.47 acres (including 816 hectares of vineyards), and, in Hungary, there remained only 21,874 hectares of agricultural land (of that, 403 hectares of vineyards) belonging the resettled Slovaks. 
Ethnological Analysis of the Process of the Post-War Migration of Slovaks from Hungary to Czechoslovakia in the Years 1946-1948

In spite of the generally positively accepted possibility of re-emigration and the promises of the more favourable outlooks on the nationality realization and economic attractiveness of their future existence in Czechoslovakia, a sort of distrust, reserve and fear of departure gradually increased among the Slovaks in Hungary. Therefore, many finally decided to stay in Hungary. Instead of 95,421 applicants, only about 70,000 persons actually left for Czechoslovakia (KUGLER 1992). These reluctant or rejecting attitudes to the issue of re-emigration had several reasons. There prevailed ambiguity in the arguments about the decision-making by the family members based on the link to family belongings, on the complicated division of the possessions (when only some members of the family decided to leave).

Attachment to birthplace and to the life created by generations (particularly to the land and the thriving agriculture) also played an important role. It is well defined by the concepts like relation to "father soil", "to the soil of great grandfathers". And last but not least, it was also their becoming aware of the fears of the "loss" of family members and the family background to be left behind in their birthplace. There were also inhibitions of a moral and ethical character, primarily owing to the method of deportation of the Hungarians from Slovakia that evoked the traumatic events experienced during the deportation of Germans, who had been their neighbours in many places in Hungary. Their decision about leaving was also affected by the uncertainty and vagueness of what was waiting for them in the "country being offered", the country with which several generations of the Slovaks living in Hungary had no closer contacts; this also had bearing on the existence of deeply controversial and paradoxical national (Slovak) consciousness and behaviour (DIVIČANOVÁ 1994:389).

On overcoming some problems associated with the process of resettlement, the population exchange was finally launched in the autumn of 1946 and was implemented in several stages. The expected improvement of the situation after resettlement suddenly changed into the situation of having to cope with the psychically onerous feeling and realizing the severance of the ties with their former "home", which struck the re-emigrants on leaving their birthplace. Parting of re-emigrants from their closest relatives, neighbours and acquaintances meant also the common prayer of the local priest in the church and the visit to the family graves in the cemetery. The leaving trains with re-emigrants were accompanied by tears and sorrow in spite of their voluntary decision to leave.

The journey of the re-emigrants to their new homeland by trains usually lasted several days. The families had their wagons - according to the size of their possessions - with their furniture, agricultural inventory, seedcom, domestic and farm animals, tools, etc. The 
MAGDALÉNA PARÍKOVÁ

Ethnological Analysis of the Process of the Post-War Migration of Slovaks from Hungary to Czechoslovakia in the Years 1946-1948

breaks during journey were used to feed and water the livestock, to cook and take care of children and old people. The journey was controlled by the bodies of the Czechoslovak and Hungarian resettlement commission, administrative and medical staff.

However, it is primarily the ethnocultural and social contexts of the re-emigration of Slovaks from Hungary that are important to ethnology. They were elucidated through field researches conducted in the regions of Slovakia, where the majority of re-emigrants settled, as well in Hungary where the re-emigrants had come from (PARÍKOVÁ 1999:19-28, 59108). Ethnology focuses on the questions of the adaptation and integration of re-emigrants into the cultural, social and natural setting in the new homeland of the particular groups of re-emigrants. Since their placement - mostly in the southern part of Slovakia - was characterized by a considerable dispersion, it was also important to direct attention toward the process of adapting in these complicated conditions especially in the initial period. The dispersions of settlements of re-emigrants (which means that they were not settled homogeneously in one locality but in its different parts) were mainly caused by the residence of re-emigrants to be resettled into a particular locality was not respected. The reemigrants from different parts of Hungary, who had no or only sporadic contacts mostly of an economic character, met in one locality. The meeting of re-emigrant families from the same locality was scarce. Thus the adaptation of re-emigrants faced thus a lengthy process of integration inside the groups of re-emigrants: the Slovak linguistic culture contained dialects of their ancestors living in the territory of Slovakia, which complicated their mutual communication. Leaving the original community interrupted their system of social roles and life "routine". They had reckoned with the change in their lives, but they had not been able to estimate its extent and the consequences after resettlement.

There were different manifestations of the traditional culture, retarding, unless they had come from the same region or locality, their mutual integration and the integration of the new community. The establishment of mutual contacts was also complicated by the local inhabitants keeping their distance from the incomers and perceiving them as "foreign", which caused friction. However, the primary reason for refusing "to come closer to" the re-emigrants coming from Hungary, was not different ethnic affiliation or language barrier (re-emigrants were mostly bilingual) but the fact that they could not cope with the situation that the incomers "occupied" the houses and land of their displaced relatives, friends and neighbours.

The process of adaptation was also difficult because of different occupations of the coming re-emigrants. The migrants coming from southern Hungary, from the Low-Land villages were almost exclusively from agricultural areas and from different social strata. 
MAGDALÉNA PARÍKOVÁ

Ethnological Analysis of the Process of the Post-War Migration of Slovaks from Hungary to Czechoslovakia in the Years 1946-1948

The medium and lower social groups of peasants prevailed. In addition, there was a large group of the so-called metal working peasants, whose agricultural production was only the secondary source of living, their main occupation being the mine and factory work. It was precisely these re-emigrants who had problems assimilating to the lifestyle that dominated in this area, that of agrarian production - till the beginning of industrialization. Although land was allocated to them, without necessary experience in farming and without necessary tools, they had problems adjusting to the new situation. This was often accompanied by misunderstanding on the part of the indigenous population whose agricultural orientation was of a high standard.

The differences in occupation did not create a platform for establishing social contacts either within the group of re-emigrants or with the indigenous farmers. Traditional interest and economic clubs stagnated as a consequence of the war events and the deportation of the indigenous population. After agricultural collec- tivization they broke up; this meant that this sphere, functioning within the traditional rural setting, conducive to forming natural links between the particular strata of the community - the level of shaping social contacts was also absent.

A welcome "starting point" for many re-emigrant families was an opportunity to decide to leave the area to live in the so-called recruitment areas of the developing industrial centres in the vicinity as well as in other regions of Slovakia. The groups of incomers who decided to stay had to face new life conditions and to adapt step- by-step. A significant role was played in this process by the joint assistance of the more experienced and better-off re-emigrants as well as of the indigenous population, who helped many reemigrant families to cope with the initial problems of adaptation. Their help focused on the manual labour (assistance in a team of animals, agricultural tools, etc.) but also on passing on experiences in agricultural production since it differed a lot from their habits and work routine used in their villages of origin in Hungary. These situations - as a necessary solution to the existence in the new setting - created opportunities for establishing closer social contacts within the groups of re-emigrants and with the local population. The collectivization of agriculture which at the beginning encountered the indignation of the overwhelming majority of village inhabitants (as in the rest of Slovakia) met with a more favourable response among poorer peasants to whom many re-emigrants belonged together with the indigenous population. The inclination of the members of these groups of the population (particularly among poorer peasants and landless persons) to the establishment of cooperatives in agriculture can be viewed as a sort of "help" in their complicated situation after resettlement - particularly with respect to their insufficient experiences with fanning. The relation of this group of re-emigrants to the allocated land was not of the 
MAGDALÉNA PARÍKOVÁ

Ethnological Analysis of the Process of the Post-War Migration of Slovaks from Hungary to Czechoslovakia in the Years 1946-1948

character of natural links to the soil, surviving through tradition, the soil being a primary treasure and the bonds having been fixed in the rural communities of traditional agrarian regions for generations. Despite the controversial situation after the establishment of cooperatives, which meant the loss of private property - of the soil as the highest in the hierarchy of the values of the farmer society, both groups in the population - the indigenous and the resettled - met at the same level working together in cooperatives. The reality of the single aim - to provide for living in the area, where, after World War II, there were no job opportunities other than agricultural work, helped to form a community of working people in spite of their different views on the formation of cooperatives, different ethnic and social affiliation as well as different origin. This, paradoxically enough, speeded up the integration inside the groups of re-emigrants as well as in relation to the indigenous population.

The situation was also difficult because Slovak re-emigrants were paradoxically made into a minority within a community of mainly Hungarian ethnic origin, which was in deep contrast to the pledges of the Czechoslovak resettlement commission offering the opportunities of freer ethnic and national self-realization (including the language). There are particular views of the re-emigrants who had come from Hun- gary that confirm it. They express the feeling of the long absence of the real "Slovak background", which had been emphasized for those interested in re-emigration as the main goal of the resettlement to Czechoslovakia. The re-emigrants also said that they had long missed any incentives that would have contributed to the crystallization and strengthening of their Slovak ethnic consciousness.

Unfortunately this also resulted from measures by the regime of the period after the resettlement. It was the period of lack of consideration of nationality in Czechoslovakia, beginning with discrimination against the Hungarian minority after the Second World War (loss of civil rights, closure of Hungarian schools, re- Slovakization), and continuing with the condemnation of "bourgeois nationalism" and "militant" declaration of ethnic identity, neglect of positive values in favour of Slovakia, and promotion of the idea of proletarian internationalism.

Such politically and ideologically motivated dogmas afflicted negatively not only the position of Slovak inhabitants (former re-emigrants) but also those who had lived in southern Slovakia before (e.g. agricultural colonists who had settled there during the 1920 land reform and after WW II). The process was reflected in the co-existence of the Slovaks and Hungarians living there. The situation in the villages of southern Slovakia that followed from the population exchange between Czechoslovakia and Slovakia serves as example. It was mainly the Church that helped people to cope with these problems, especially the 
MAGDALÉNA PARÍKOVÁ

Ethnological Analysis of the Process of the Post-War Migration of Slovaks from Hungary to Czechoslovakia in the Years 1946-1948

Evangelical of Augsburg creed and the Baptist Church. They created a certain background for re-emigrants in spite of the long period of atheization of society in former Czechoslovakia. Although there were efforts to create optimum conditions for their existence in the new homeland and for their social existence in the broadest sense of the word as quickly as possible, there were situations of tension and often of bilateral distancing of the re-emigrants from the indigenous population, but also within the groups of re-emigrants. On the part of re-emigrant groups it was a sort of looking for a compensation for their feeling of being a minority within the majority (Hungarian) society and demonstrating their "prestigious" manifestations in their way of life and culture, which might have been an "answer" to some rancour, or disasso- ciation of the indigenous population.

Tension and/or intolerance in the coexistence between the re-emigrants and the indigenous population and in their mutual contacts were most conspicuously demonstrated and felt - according to the people living there - in the years of 'breakthrough' political events. We see this problem as simplified to look at it only from the perspective of different ethnic affiliation of the two groups of population living next to each other. Predominance of the causes of "disharmony" in mutual relations, just because they are more often associated with some important social and political changes, has its roots in the wider circumstances and/or events concerning the "neuralgic" periods of recent history of their mother nations, Magyars and Slovaks. These were, also as a result of the unilateral political and ideological interpretation on both sides, reflected on the relations between both ethnic groups. Most sensitive was the reflection of the "latest" event which interfered in the everyday life of every individual.

The first period of adaptation in the new environment and the difficult situation was mitigated by the fact of the allocation of the land - often of much larger area than they had in Hungary. But this did not always bring the reality of a more favourable social and economic future - till the collectivization in agriculture - levelled off the other problems associated with the adaptation of re-emigrants.An equally sensitive issue among reemigrants was the loss of the family and social background since most families - on both sides of those who participated in the population exchange - had their relatives in their original homeland. Family was shown to play an important role in the process of the adaptation of re-emigrants to the new ethno-social milieu. It was usually a one-generation family because multigeneration families of parents with children and grandparents had rarely decided to resettle. Family operated as a factor slowing down the adaptation and integration, mainly because of the conservatism of parents or a grandparent who kept to the traditional pattern of the family's life in the country of their origin for generations. This was 
MAGDALÉNA PARÍKOVÁ

Ethnological Analysis of the Process of the Post-War Migration of Slovaks from Hungary to Czechoslovakia in the Years 1946-1948

also due to the persisting one residence for a re-emigrant family (parents with the young family and children living in one house and running a common household), because there were no conditions to live in separate houses. It was also caused by the state's practice of maintain a housing depression after declaring some villages in southern Slovakia to be "non-prospective".

The feeling of estrangement, broken family contacts, the attitude of an accepting community toward re-emigrants immediately after resettlement, increased the distance of re-emigrants from the surroundings that had the signs of strict endogamy. That was the reason why the family had long remained the social unit that tried to provide its members with a sufficient psychic and emotional background nourishing their earlier and longer lasting contacts with their relatives, neighbours and friends in the old homeland. Not only the parents' conservatism but also taking account of the will of their children (mainly the single ones) ensuing from the emotional ties, esteem and the awareness of the potential sanctions of moral character, increased the authority of the family within the process of the re-emigrants' integration. Economic dependence of children on their parents also contributed to this. Traditional stereotypes of family ties to which particularly the older generation of re-emigrants clung often led to misunderstandings. The greatest opinion clashes used to arise mainly in connection with the emancipatory efforts of younger family members, who were more prone to adjust to the new situation. Such an intergeneration "confrontation" often weakened the meaning of the traditional stereotypes, mainly as a result of the improved conditions for the separation of the young people, later leading to intermarriages. The absence of the family ties (which were ended by re-emigration) was compensated by closer contacts within the groups of re-emigrants which resulted, in the following generations, in marriages exclusively within the society of re-emigrants. This reality led for a certain period of time to group and local endogamy. It was also due to the long-term awareness of common origin, equal "fate" and fixed almost up to now (also in the generation already bom in Slovakia) in the ethnonym of these groups - re-emigrants but also due to their social status, religion (mostly Evangelical), the way of settlement in those localities, and acceptance of the groups by the members of the majority Hungarian population who perceived them as "foreign" and, moreover, as those living in the dwellings of their displaced relatives, neighbours, and friends. Such an opposition expressed in the strict relation or distance "we" and "they" determined the willingness, forms and intensity of mutual social communication of "home" and "in-migrated". A slow release and change in the strict application of endogamy of both groups that met as a result of the population exchange led to more intense and more frequent and closer contacts. They were based on the close proximity between the local population, labour contacts and cooperation 
MAGDALÉNA PARÍKOVÁ

Ethnological Analysis of the Process of the Post-War Migration of Slovaks from Hungary to Czechoslovakia in the Years 1946-1948

(paradoxically enough, at the beginning particularly in connection with the agricultural collectivization), then the increased mobility of the productive population, school attendance, but also military service.

The analysis of the results from the field research showed that the manifestations of group endogamy survived in relation to different social and religious affiliations of the population rather than as a consequence of their different ethnicity. The most striking example supporting it is the existence of ethnically mixed marriages, where the parallel use of both the Slovak and the Hungarian languages (in education as well as in family and local communication) is not rare. Of course, rejections or unwillingness to incline to the communication exclusively in Slovak or only in Hungarian are not exceptional. Bilingualism was and still is a prerequisite for such a practice (a command of Slovak and Hungarian), particularly by the members of older and middle generation of re-emigrants and the following, expected preference of the majority language, that of the local Hungarian ethnic community.

A traumatizing phenomenon accompanying the process of re-emigration was the settlement of part of the Slovak re-emigrants - in contrast to the pledges of the Czechoslovak government - in the Czech border regions, in the emptied farms of the displaced German population. Only some families and individuals from this group of reemigrants succeeded in moving to Slovakia after some time (GYVICSÁN 1990).

The analysis of the process of adaptation and integration of the Slovak re-emi- grants in southern Slovakia is only one of the outlooks on the consequences of postwar migration population exchange between Czechoslovakia and Hungary - for the people living in Central Europe. Although the stage of migration took place 67 years ago, its impact on the existence of the particular communities is observable even today. However, the conclusions drawn cannot be applied to whole regions since every individual creates either a negative or a positive image of a particular historical reality and its consequences usually on the basis of his own experiences. Nobody can take such a right from him/her. Incentives coming from "outside" also play a certain role, not always positively influencing perception of his own historical experience. This is probably the reason why the assignment of scientific investigation - in our case that of ethnology - is to look at the separation of the sphere of political assessment from the "real relations among people", who are the only ones to know the real image and the form of their co-existence. Their attitudes and statements appeal, however, to those who "arrogate" to themselves the right to decide on such important issues as migration of population. 


\section{Conclusion}

The results of the ethnological analysis of the post-war migration of the Slovak expatriates from Hungary to Czechoslovakia in the years 1946-48 is an important period of post-war migrations in Europe.

Because it was not possible to focus in this contribution on wider range of issues related to the processes of social and cultural adaptation of reemigrants to the country of their ancestors in detail, we concentrated on the analysis of material from the field research - concretely from the narrative interviews. The obtained findings point to the fact that the studied process of the migrations represents a dynamic phenomenon accompanied by moving ( resettlement), new social and cultural contacts, processual changes (adaptation, integration ).

The analysis of narratives also showed that during the socialization process not only of the displaced persons, but also of the original (autochthon) community also the stimuli from "outside" have impact, not always positively affecting reception of the own historical experience of the individual.

We assume, that this is why in the interviews with respondents (both reemigrants and the autochthon population) we recorded the attitudes, urgently separating the sphere of political context "from the real relations between common people", who are the only ones to know the real situation.

These findings largely contribute to the objectiveness of the scientific view of the migration process.

\section{References}

BOBÁK, J. (1996): Mad’arská otázka v Československu /1944-48/. Bratislava, 119 p.

BOTíK, J. (1995): Etnokultúrne procesy v podmienkach etnického rozdelenia. Slovenský národopis 4/1995, pp. 431-445.

ČIERNA-LANTAYOVÁ, D. (1992): Political and Human Aspects of the Repatriation of Slovaks from Hungary. Human Affairs, 1992, pp. 173-182.

DIVIČANOVÁ, A. (1994): Etnokulturne zmeny na slovenskych jazykovych ostrovoch v Mad'arsku. Slovenský narodopis 1994, pp. 264-283. 
MAGDALÉNA PARÍKOVÁ

Ethnological Analysis of the Process of the Post-War Migration of Slovaks from Hungary to Czechoslovakia in the Years 1946-1948

GYVICSÁN, A. (1990): K etnokultúrnemu vývinu Slovákov v Mad'arsku /Náčrt o kúlturnom dedičstve Slovákov žijúcich v Čechách/. Český lid, 1990, pp. 203-211.

GYVICSÁN, A. (1993): Anyanyelv, kultura, kozősség. A magyarországi szlovákok. Budapest 1993, $343 \mathrm{p}$.

KOŘALKOVÁ, K. (1986): Reemigrace krajanů jako součást migračných změn v Československu po druhé světové válce. In: Etnické procesy v pohraničí českých zemí po roce 1945. Etnické procesy 3 (Společnost a kultura 1), Praha 1986, pp.162 -174.

KUGLER. J. (1992): A magyar-csehszlovák lakósságcsere délkelet - Alföldi toörténete es népesség-földrajzi vonatkozásai. Manuscript of the dissertation. Békéscsaba 1992, $250 \mathrm{p}$.

LETAVAJOVÁ, S. (2005): Orálna história a výskum cdzincov na Slovensku /Úskalia a výhody/. In. Zuzana Profantová led./: Malé dejiny vel'kých udalostí v Česko- /a/ Slovensku po roku 1948,1968,1989. Etnologické štúdie 13, Bratislava, pp.150-169.

PARÍKOVÁ, M. (2001): Reemigrácia Slovákov z Mad'arska v rokoch 1946-48. Etnokultúrne a sociálne procesy. Bratislava, 284 p.

PARÍKOVÁ, M. (2010): Orálna história a možnosti jej využtia pri skúmaní enokultúrnych procesov (Analýza výsledkov etnologického výskumu $\mathrm{v}$ prostredí presídlencov na južnom Slovensku). In. Z.Šápošová-Š.Šutaj, eds., Povojnové migrácie a výmena obyvatel'stva medzi Československom a Mad'arskom. Prešov: Universum, pp. 212-221.

SIRÁCKY. J. (1996): St’ahovanie Slovákov na Dolnú zem v 18. a 19. storočí. Bratislava.

ŠUTAJ, Š. (1993): Mad'arská menšina na Slovensku v rokoch 1845-1948. Bratislava, $196 \mathrm{p}$.

ŠUTAJ, Š. (2010): Výmena obyvatel'stva medzi Československom a Mad'arskom migrácie a Slovensko - výskumy a výsledky. In. Z.Šápošová-Š.Šutaj, eds., Povojnové migrácie a výmena obyvatel'stva medzi Československom a Mad’arskom. Prešov: Universum, $221 \mathrm{p}$. 